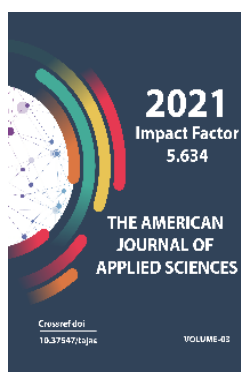

Journal Website: http://usajournalshub.c om/index,php/tajas

Copyright: Original content from this work may be used under the terms of the creative commons attributes 4.0 licence.

\section{To Learn Of Biological And Productive Indicators Of Imported Mulberry Silkworm Breeds}

\author{
Soliyeva M.B.
}

Senior Teacher, Andijan Agriculture And Agri-Technologies Institute, Uzbekistan

Tuychiev J.Sh.

Associate Professor, Andijan Agriculture And Agri-Technologies Institute, Uzbekistan

Asronov E.K.

Senior Teacher, Andijan Agriculture And Agri-Technologies Institute, Uzbekistan

\title{
ABSTRACT
}

Biological and productivity indicators of imported Kinsyu and Syova breeds were studied in the conditions of Uzbekistan. In the experiment, it was found that the duration of the worm period of the Kensyu breed was one day shorter than the Asaka breed and the viability of the worms was $6 \%$ higher. In the Syova breed, the duration of the worm period was found to be 0.5 days shorter and the survival rate was $9 \%$ higher.

\section{KEYWORDS}

Cocoon, temperature, humidity, varietal cocoons, spotted cocoons, biological indicators, mulberry leaves, high productivity, preserved live cocoons, cocoon production, live cocoon, productivity, varietal cocoons, technological indicators.

\section{INTRODUCTION}

The influence of external environmental factors on the expression of the genetic characteristics of any plant and animal is great. Variability of factors such as air temperature, relative humidity, light, nutrients and its quantity in the place where the organism lives will inevitably affect the biology, physiology, fertility and ultimate productivity of plants and animals. 
Of course, the interaction of organisms with the external environment is not the same depending on the animal and plant species.Warm-blooded animals are more resistant to external factors. The growth and development of mulberry silkworm, which belongs to the class of cold-blooded or poikilothermic insects, and its biological concentration and productivity, of course, depends on the climatic conditions of the place where it lives.

\section{MAIN PART}

Darwin $(1839,1841,1851)$ was one of the first to substantiate the scientific theory of variability in the population of organisms as a result of changes in the external environment.

Indeed, the living beings around us are constantly changing. Such variability can be observed at any time in crops, farms, experimental fields F.A.Dvoryankin (1964).R.U. Valiev $(1993,1996)$ argues that on the basis of his experience it is necessary to create nutrition and external conditions regimes to such an extent that they can demonstrate the potential of heredity. A.V. Anuchin (1926) was one of the first to study the variability of mulberry silkworm cocoons, arguing that the influence of external conditions, i.e. feeding and temperature, is extremely important in the care of worms.

A.B. Yakubov (1997), E.H Tadjiev (1997) argue that the growth and development of mulberry silkworms can not be achieved without creating a certain temperature limit. U.N.Nasirillaev, S.S.Lejenko (1994) found that in the process of creating large-cocoon Orzu and Yulduz breeds, there are large and cocoonwrapped families, as well as families with high fertility. It should create certain conditions for families with such a genotype to realize their potential.

It should be noted that the high-yielding characteristics of the silkworm are passed from the parental to the next generation through the eggs. In order to breed breeding eggs, the development of breeding worms with their parents should be provided with a certain level of larvae, temperature and humidity regime, as well as feeding for the breeding cocoon.

As mentioned above, the growth, development and productivity of agricultural plants and animals are closely related to external factors. In other words, the manifestation of the characteristics that each organism receives from its parents through the egg cell and sperm takes place under certain conditions.

When high-yielding animals are fed with low and poor quality feed, the opportunities available in their genetics are not realized, and as a result, such animals are among the average individuals in terms of economic performance. This, in turn, leads to errors in the selection process.Similar experiments were conducted by B.F Pilipenko. He writes that hybrids with high silkworm are very demanding to external conditions. High-yielding hybrids may have low yields when feeding and care conditions deteriorate.

Therefore, in order to ensure a high level of productivity, it is necessary to provide a complete and uninterrupted supply of nutrients to the breeding organisms for reproduction and to create the necessary environmental conditions. 
Extensive use of agro-technical methods and creation of necessary conditions are of special importance in the cultivation of mulberry silkworms, especially in the breeding of cocoons from breeding worms.

The main purpose of experiments in this area is to create the necessary zootechnical conditions to fully demonstrate the productivity characteristics of silkworm breeders achieved by breeders. In recent years, the country has been importing mulberry silkworm seeds.The origin of imported silkworm hybrids for cultivation of industrial cocoons, maintenance agrotechnics, cocoon yield, quality and technological features are poorly studied in our country. As a result, the quantity and quality of cocoons grown in the country are not in demand. Analysis of the cocoon yield obtained from them shows that the imported mulberry silkworm is not able to demonstrate its domestic potential in the climatic conditions of our country.

The better we understand the relationship between the organism and the external environment, the better we can manage the organism, taking advantage of the opportunity to regulate and create the external environment. Therefore, the interaction between the organism and the environment is of particular importance for agriculture, and good breeds of animals are formed only as a result of the application of good agronomics and good zootechnics.

To solve this problem, to bring the quality and technological parameters of silkworms to the level of world market requirements by improving the yield, quality and technological properties of cocoons by adapting imported silkworm breeds and hybrids to the conditions of Uzbekistan.

The urgency of the topic is the development of the silkworm industry of the Republic by creating new promising breeds and hybrids, recommending them for production. Based on the above scientific research, we have a theoretical understanding that the biological and productivity of silkworm eggs can be changed for the better through the management of environmental factors in the process of incubation, care, cocooning.

To accomplish this task, we set ourselves the task of identifying the following indicators.In the experiment, to study the biological and productivity characteristics of mulberry silkworms "Kinsyu" and "Syova" imported from Japan, 800 seeds were selected from 4 seeds of 200 replicates and variants were created. In 4 replicates in each variant, a revival rate of 3200 worm seeds was determined.

The revived Kinsyu breed was identified as the first experimental variant, and our Asaka breed was taken as a control variant. The Syova breed was identified as the third experimental variant, and our Marxamat breed was taken as a control variant. Each experimental variant fed 4 silkworms in 4 replicates, and 200 silkworms in each replication and 800 variants in one variant.

\section{RESULTS AND DISCUSSIONS}

A total of 3200 silkworms were reared in 4 variants of the experiment.The silkworms in the experiment were cared for on the basis of agrotechnical measures adopted for the white cocoon breeders, all agrotechnical measures were carried out on the same day and at the same time. 
The following indicators were identified in the experiment:

- Revival of silkworm seeds, in\%.

- The duration of the silkworm by age, in days.

- The duration of the worm period, in days.

- Worm life, in\%.

- Average weight of one live cocoon, gr.

- Silk of a living cocoon,\%.

In order to study the technological characteristics of the silkworm cocoons of high-yielding mulberry silkworm breeds "China 108" and "China 122" imported from China, 800 seeds were selected from the seeds of "China 108", "Asaka", "China 122" and "Marhamat" breeds in 4 turns. were taken and options were created. In 4 replicates in each variant, a revival rate of 3200 worm seeds was determined.

The revived Chinese 108 breed was identified as the first experimental variant, and our Asaka breed was taken as a control variant. The Chinese 122 breed was identified as the third experimental variant, and our Marxamat breed was selected as the control variant.

The silkworm seeds placed in the incubator for resuscitation were produced for white cocoon breeders at a room temperature of $240 \mathrm{~S}$ and a relative humidity of $75 \%$.

Silkworms were fed in 4 reps of each experimental variant, 200 in each replication, and 800 in one variant. A total of 3200 silkworms were isolated for all variants of the experiment.

The silkworms in the experiment were cared for on the basis of agrotechnical measures adopted for the white cocoon breeders, all agrotechnical measures were carried out on the same day and at the same time. 20 eggs were cast from the Kinsyu silkworm breed and 5 variants were created. Each variant was counted from 200 seeds in 3 repetitions, and the total viability was determined by taking 3000 seeds for a total of Kinsyu breed. In comparison with this breed, three eggs of Asaka breed of silkworm, bred in the district, were obtained and one variant was created to compare the viability of 200 silkworms in 3 replicates for a total of 600 seeds. In the same way, the seeds of the Syova breed were put to life, and the Marhamat silkworm breed, which is bred in the district, was obtained as a comparison.

Table 1.

Biological parameters of silkworm breeds "Kinsyu" and "Syova"

\begin{tabular}{|c|c|c|c|c|c|c|}
\hline $\begin{array}{c}\text { Experiment } \\
\text { options }\end{array}$ & $\begin{array}{c}\text { Worm } \\
\text { period }\end{array}$ & $\begin{array}{c}\text { The viability } \\
\text { of worms } \\
\text { per day. }\end{array}$ & $\begin{array}{c}\text { Weight of } \\
\text { one cocoon, } \\
\text { gr }\end{array}$ & $\begin{array}{c}\text { Weight of } \\
\text { cocoon shell, } \\
\text { gr }\end{array}$ & $\begin{array}{c}\text { Quantit } \\
\text { y of } \\
\text { cocoon } \\
\text { s }\end{array}$ & Silk\%. \\
& & & & & & \\
\hline
\end{tabular}


The American Journal of Applied sciences (ISSN - 2689-0992)

Published: April 29, 2021 | Pages: 131-137

\begin{tabular}{|c|c|c|c|c|c|c|}
\hline $\begin{array}{c}\text { Kinsyu breed- } \\
\text { experience }\end{array}$ & 24,0 & 95.0 & 2.0 & 0.550 & 89.8 & 27.5 \\
\hline $\begin{array}{c}\text { Comparative } \\
\text { Asaka breed }\end{array}$ & 25.0 & 89.0 & 1.8 & 0.450 & 81.5 & 25.0 \\
\hline $\begin{array}{c}\text { Syova breed } \\
\text { experiment }\end{array}$ & 24.5 & 93.0 & 2.0 & 0.570 & 90.1 & 28.5 \\
\hline $\begin{array}{c}\text { Comparative } \\
\text { "Marxamat" } \\
\text { breed }\end{array}$ & 25.0 & 84.0 & 1.8 & 0.425 & 82.9 & 23.5 \\
\hline
\end{tabular}

Based on the results obtained, the mulberry silkworm breeds imported from abroad have really shown their productivity. This was evident when we analyzed the biological parameters of the silkworms fed.In both species we can see that the biological parameters of worms are several times higher than those of the comparator. Worms in highviability variants have been shown to have higher cocoon weight and cocoon shell weight.
The productivity of new silkworm breeds is also reflected in silkworm breeding, which is an important indicator. This figure was $26-27 \%$ in live cocoons. The weight of the cocoon shell was $0.550-0.570$ grams.These figures show that mulberry silkworms imported from abroad are superior to domestic silkworms, which are now widely fed in production.

Table 2.

Variety indicators of silkworm cocoons in the experiment

\begin{tabular}{|c|c|c|c|c|c|c|c|}
\hline \multirow{2}{*}{$\begin{array}{l}\text { Experiment } \\
\text { options }\end{array}$} & \multirow{2}{*}{$\begin{array}{c}\text { Analyzed } \\
\text { cocoon, pcs }\end{array}$} & \multicolumn{6}{|c|}{ Percentage of varietal and defective cocoons,\%. } \\
\hline & & varietal \% & $\begin{array}{c}\text { Scarred } \\
\%\end{array}$ & Spotted\% & $\begin{array}{l}\text { Thin } \\
\text { shell\% }\end{array}$ & $\begin{array}{c}\text { Atlas } \\
\%\end{array}$ & Blackberry\% \\
\hline $\begin{array}{c}\text { Kinsyu breed } \\
\text { Experience }\end{array}$ & 100 & 89.8 & 2.20 & 4.60 & $1.0-$ & 1.20 & 1.20 \\
\hline $\begin{array}{c}\text { Control } \\
\text { Asaka breed }\end{array}$ & 100 & 81.5 & 3.50 & 8.50 & 1.5 & 2.50 & 2.5 \\
\hline $\begin{array}{l}\text { Syova breed } \\
\text { Experiment }\end{array}$ & 100 & 90.1 & 1.30 & 4.80 & 1.30 & $1.00-$ & 1.50 \\
\hline
\end{tabular}


The American Journal of Applied sciences

(ISSN - 2689-0992)

Published: April 29, 2021 | Pages: 131-137

\begin{tabular}{|c|c|c|c|c|c|c|c|}
\hline $\begin{array}{c}\text { Control } \\
\text { "Marxamat" } \\
\text { breed }\end{array}$ & 100 & 82.9 & 2.80 & 7.5 & 2.5 & 1.60 & 2.70 \\
\hline
\end{tabular}

Defective cocoons in the experimental variants accounted for 10.2 percent of the cocoons isolated from the Kensyu breed, 18.5 percent of the cocoons grown from the Asaka breed in the control variant, 9.8 percent in the Syova breed, and 17.1 percent in the controlled Marxamat breed.

\section{CONCLUSION}

This means that the imported Kensyu and Syova breeds of silkworms had higher biological performance than ours, and were more resistant to various diseases, so the cocoons they wrapped had a high content of quality cocoons.The resuscitation of seeds of Kensyu and Syova breeds imported from Japan is 0.5 days less than that of Asaka and Marxamat breeds.

In both species we can see that the biological parameters of worms are several times higher than those of the comparator. Worms in highviability variants have proven their productivity in the weight of the cocoon and the thickness of the cocoon shell.

\section{REFERENCES}

1. Туйчиев, Ж. Ш., Убайдуллаев, С. Ш., Турдиева, Ф. Т., \& Солиева, М. Б. (2015). ИЗМЕНЕНИЕ ДОЛИ ДЕФЕКТНЫХ КОКОНОВ В ЗАВИСИМОСТИ ОТ СРОКОВ ПОСТУПЛЕНИЯ НА ЗАВОД. Современные тенденции развития науки и технологий, (4-2), 78-81.
2. Sharipovich, A. A., Sheralievich, Y. N., Botirovna, S. M., \& Mukhammadovna, E. J. (2020). Study of methods for identification and storage of morphological features of grapes grown in the conditions of Fergana Region. The American Journal of Agriculture and Biomedical Engineering, 2(07), 20-24.

3. Sokhibova, N. S., Nazirova, M. I. K., \& Botirovna, S. M. (2020). INFLUENCE OF REARING SILK WORMS WITH HIGH PRODUCTIVE MULBERRY LEAVES ON THE BIOLOGICAL INDICATORS OF SILK GLAND AND RAW SILK EFFECTIVENESS. Life Sciences and Agriculture, (2).

4. Asronov, E. K., \& Soliyeva, M. B. (2020). The importance of feeding silkworms under polyethylene. ACADEMICIA: An International Multidisciplinary Research Journal, 10(10), 1169-1174.

5. Yuldasheva, K. T., Soliyeva, M. B., Kimsanova, X. A., Arabboev, A. A., \& Kayumova, S. A. (2021). Evaluation of winter frost resistance of cultivated varieties of olives. ACADEMICIA: AN INTERNATIONAL MULTIDISCIPLINARY RESEARCH JOURNAL, 11(2), 627-632.

6. Xatamova, X. K., Yuldasheva, K. T., Soliyeva, M. B., Kimsanova, X. A., \& Juraboyeva, S. M. (2021). Methods of preserving subtropical fruits. Asian Journal of Multidimensional Research (AJMR), 10(1), 109-115.

7. Yuldasheva, K. T., Soliyeva, M. B., Xatamova, X. K., \& Kimsanova, X. A. (2020). Effect of arbuscular mycorrhiza on 
The American Journal of Applied sciences (ISSN - 2689-0992)

Published: April 29, 2021 | Pages: 131-137

micro propagated olive. ACADEMICIA: AN INTERNATIONAL MULTIDISCIPLINARY RESEARCH JOURNAL, 10(12), 1491-1498.

8. ВАХОБОВ, А., СОЛИЕВА, М., \& ХАТАМОВА, $\quad$. КРАСНОКОЧАННОЙ КАПУСТЫ ДЛЯ ПОВТОРНОЙ КУЛЬТУРЫ. ИРРИГАЦИЯМЕЛИОРАЦИЯ, 57.

9. Туйчиев, Ж. Ш., Мирзаев, Р. О., Солиева, М., \& Гафурова, Ю. К. (2016). ЗАВИСИМОСТЬ КАЧЕСТВА КОКОНОВ ПЕРВИЧНОГО ПОКОЛЕНИЯ ОТ КОЛИЧЕСТВА ФОРМ ИЗМЕНЕННЫХ ИЗ ПАРТИИ ПЛЕМЕННЫХ. СовременнЫе тенденции развития науки $и$ технологий, 124.

10. Асронов, Э. К., \& Солиева, М. Б. (2020). ВЛИЯНИЕ ИЗМЕНЕНИЯ ТЕМПЕРАТУРЫ НА ПРОДУКТИВНОСТЬ И КАЧЕСТВО КОКОНОВ ВО ВРЕМЯ КОРМЛЕНИЯ ТУТОВОГО ШЕЛКОПРЯДА. Экономика и социум, (12-1), 388-391.

11. Асронов, Э. К., Салиева, М. Б., Салиев, С. А., \& Давлатов, Х. Р. (2018). ХРАНЕНИЕ ПЛОДООВОЩНОЙ ПРОДУКЦИИ. In Северный морской путь, водные и сухопутные транспортные коридоры как основа развития Сибири и Арктики в XXI веке (рр. 264-266).

12. Soliyeva, M.B., Yuldasheva, Kh.T., Xatamova, X.K., Kimsanova, X.A., Isroilova, Sh.Sh. (2021). THE EFFECT OF SHELF LIFE OF LIVE COCOONS ON THEIR TEMPERATURE AND QUALITY. Asian Journal of Multidimensional Research (AJMR), 10(3), 254-260. 